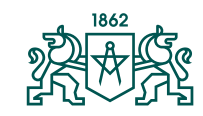

RIGA TECHNICAL UNIVERSITY
No. 5, Sept. 2021, pp. 153-178 https://doi.org/10.7250/HESIHE.2021.008

\title{
CHRONOLOGY OF KEY EVENTS OF RIGA TECHNICAL UNIVERSITY
}

\author{
IN STUDY YEAR 2020/2021
}

\section{0}

\section{September 1}

RTU Engineering High School (EHS) hosts a Knowledge Day event with the participation of Minister of Education and Science Ilga Šuplinska and one of EHS supporters, a graduate (1986) of the Riga Polytechnic Institute (RPI; now RTU) entrepreneur, Chairman of the Board of JSC «SAF Tehnika» Normunds Bergs.

http://www.izv.lv/2020/08/rtu-inzenierzinatnu-vidusskolu-1-septembri-apmeklesizglitibas-un-zinatnes-ministre-ilga-suplinska/

\section{September 2}

Ilmārs Bērziņ̌s, a graduate of the Institute of Design Technologies (IDT) of the RTU Faculty of Materials Science and Applied Chemistry (FMSAC), wins second place in the nomination «The most sustainable student idea 2020» in the 2020 competition «Sustainability in Architecture, Construction, Design» nomination; graduate of IDT Nadina Anija Poga obtained competition jury recognition nomination.

https://www.rtu.lv/lv/universitate/masu-medijiem/zinas/atvert/ rtu-dizaina-tehnologiju-studentu-darbi-apbalvoti-ilgtspejigu-ideju-konkursa

\section{September 7-13}

Pupil of RTU EHS Daniels Stabulis wins a silver medal at the International Economic Olympiad.

https://www.rtu.lv/lv/universitate/masu-medijiem/zinas/atvert/rtuinzenierzinatnu-vidusskolas-skolnieks-izcina-sudraba-medalu-starptautiskajaekonomikas-olimpiade

\section{September 11}

Meeting of the traditional RTU Rector Academician Leonìds Ribickis with the teaching staff and students, starting the new study year is held. For the first time, the event can also be watched online on the internal RTU portal ORTUS.

For the first time, an informative day for freshmen «Startēšu RTU» is taking place online.

https://www.rtu.lv/lv/universitate/masu-medijiem/zinas/atvert/isi-pirmsakademiska-studiju-gada-sakuma-jaunos-studentus-tiessaiste-aicina-iepazit-rtu 


\section{September 14}

Students meet at the traditional RTU Freshmen Meeting Festival.

https://www.rtu.lv/lv/universitate/masu-medijiem/zinas/atvert/

rtu-iezvanisanas-svetki-2020-1

\section{September 18}

In honour of the chemical scientist Emìlija Gudriniece (1920-2004) and celebrating the academician's 100th birthday, «Latvijas Pasts» (Latvia Post) issues a new stamp and envelope.

https://www.pasts.lv/lv/zinas/filatelijas_zinas/5874-rigas-tehniskas-universitatesmaterialzinatnes-un-lietiskas-kimijas-fakultate-prezentes-kimikei-emilijaigudriniecei-veltitu-pastmarku

\section{September 19}

Student of the RTU Faculty of Architecture (AF) Katrīna Sproǵe is elected the President of the Student Union of Latvia.

https://www.delfi.lv/news/national/politics/latvijas-studentu-apvienibasprezidenta-amata-ievele-katrinu-sprogi.d?id=52484263

\section{September 24}

This year's graduate of RTU EHS Kārlis Šusters is winning a bronze medal at the International Informatics Olympiad for the second year in a row. https://www.rtu.lv/lv/universitate/masu-medijiem/zinas/atvert/rtuinzenierzinatnu-vidusskolas-absolvents-karlis-susters-izcina-bronzas-medalustarptautiskaja-informatikas-olimpiade

\section{September 28}

With the decision of the Senate of RTU (Minutes No. 642):

- the title «RTU Honorary Alumnus 2019» has been awarded to the President and Chairman of the Board of Ltd. «Latvijas mobilais telefons» Juris Binde;

- $\quad$ Professor Ériks Geriņš has been appointed Dean of the Faculty of Mechanical Engineering, Transport and Aeronautics (FMETA) for another term.

\section{September 29}

The Topping-out Celebration of the new building of the RTU Faculty of Computer Science and Information Technology (FCSIT) and the shared auditorium centre is taking place in Kīpsala, 10 Zunda krastmala.

https://www.rtu.lv/lv/universitate/masu-medijiem/zinas/atvert/ rtu-datorzinatnes-un-informacijas-tehnologijas-fakultate-svines-sparu-svetkus-1 


\section{In September}

In the prestigious «The Times Higher Education (THE) World University Rankings 2021», RTU has been recognized as the 284th best university in the world, evaluating the cooperation of universities with industry. https://www.rtu.lv/lv/universitate/masu-medijiem/zinas/atvert/rtu-labakalatvijas-augstskola-finansejuma-piesaiste-no-industrijas?fbclid=IwAROKIkT9MMk-i7KnTysUk3T9gCZoHTJA2IrguwUPnqKvmQq26X $m s X_{-} U j G c$

\section{October 1-2}

RTU celebrates the World Association of Engineers Day - «IEEE Day». http://mttw.org/

\section{October 5}

In connection with the amendments to the Law on Higher Education Institutions submitted to the Saeima of the Republic of Latvia (RL), which envisages changing the higher education governance model by introducing councils, the RTU Constitutional Assembly addresses the Cabinet of Ministers of the Republic of Latvia with a request to postpone RTU rector elections. According to order No. 38 of the Cabinet of Ministers on 27.01.2016. «On approval of the Rector of Riga Technical University» RTU Rector Leonīds Ribickis has been confirmed in position on 02.02.2016. Point 2 of the Article 17 of the Law on Higher Education Institutions stipulates that the Constitutional Assembly of a higher education institution elect the Rector for a term not exceeding five years.

\section{October 8}

RTU Honorary Doctor (2007) Ivars Kalviñš is elected President of the Latvian Academy of Sciences (LAS).

https://www.delfi.lv/news/national/politics/

par-zinatnu-akademijas-prezidentu-ievel-ivaru-kalvinu.d?id=52543663

Two RTU graduates receive (LAS) awards: Mg. chem. Mikus Purin̄̌ received the Award named by Emilija Gudriniece for his master's thesis (supervisor Māris Turks); Dr. sc. ing. Andris Freimanis received the Award named by Vitauts Tamužs for the doctoral thesis (supervisor Dr. sc. ing. Ainārs Paeglītis). RTU EHS teacher Dr. phys. Virginija Vìtola receives the LAS Young Scientist Award.

https://www.lza.lv/aktualitates/jaunumi/208-lza-arkartas-pilnsapulce-tikapasniegtas-akademijas-vardbalvas-un-balvas-jaunajiem-zinatniekiem 


\section{October 9}

The traditional RTU History Day is taking place.

https://www.rtu.lv/lv/universitate/masu-medijiem/zinas/atvert/

rtu-158-dzimsanas-dienas-svinibas-aizsaks-vestures-diena

\section{October 12}

In honour of the founders and former rectors of our university, representatives of RTU administration and the Student Parliament (SP), as well as RTU RCEH visit their resting places in Riga cemeteries.

https://www.rtu.lv/lv/muzejs/galerija-2/kategorija/

godina-musu-augstskolas-dibinatajus-un-bijusos-rektorus-13-10-2020

\section{October 14}

To mark the 158th anniversary of RTU, a solemn sitting of the RTU Senate and a plenary sitting of the 61st International Scientific Conference are taking place.

https://www.rtu.lv/lv/universitate/masu-medijiem/zinas/atvert/ rtu-158-dzimsanas-diena-sumina-izcilakos-zinatniekus-un-macibspekus

At the ceremonial sessions, the most outstanding scientists, lecturers are awarded and RTU Honorary Alumnus is honoured - for the support of engineering studies, the title «RTU Honorary Alumnus» has been awarded to the President of LMT and Chairman of the Board Juris Binde.

The award «RTU Scientist of the Year 2020» is awarded to the Dean of FMSAC, Academician Mãris Turks; the award «RTU Young Female Scientist of the Year 2020» is awarded to Researcher at the Institute of General Chemical Engineering of FMSAC Liga Stipniece; the award «RTU Young Scientist of the Year 2020» - is awarded to Leading Researcher of the Institute of Materials and Structures of the Faculty of Civil Engineering (FCE) Girts Būmanis; Viktors Haritonovs, a Leading Researcher at the Institute of Transport Infrastructure Engineering of FCE, receives the Annual Award in Valorisation; Jānis Braunfelds, a doctoral student and a Researcher at the Institute of Telecommunications of the Faculty of Electronics and Telecommunications (FET) receives the Annual Student Award in Valorisation.

Professor Dagnija Blumberga, Director of the Institute of Energy Systems and Environment of the Faculty of Electrical and Environmental Engineering (FEEE), receives the «RTU Annual Academic Excellence Award 2020»; the title «RTU New Teacher of the Year 2020» has been awarded to Leading Researcher at the Institute of Radioelectronics of FET Anna Litvinenko. 
The solemn sitting of the Senate also congratulates more than 30 RTU lecturers on the training of young scientists, honours the teachers of RTU EHS, several RTU employees receive RTU Honorary Diplomas.

https://www.rtu.lv/lv/universitate/masu-medijiem/zinas/atvert/ rtu-158-dzimsanas-diena-sumina-izcilakos-zinatniekus-un-macibspekus

Raimonds Bagdanovičs, a student of the FCE, and Raivis Jānis Mucenieks, a Master's student of the FA, receive the title «Student of the Year 2020» and a cash prize at the traditional «Construction Industry Grand Prix 2020» ceremony. RTU, in turn, receives the special award of the company «Sakret»- «Kadru kalve».

http://lielabalva.lv/buvindustrijas-izcilniekiem-pasniegti-12-pamatakmeni/

\section{October 16}

To get acquainted with RTU research in energy, FEEE is visited by a delegation of the Ministry of Economics, which also is attended by the Minister of Economics Jānis Vitenbergs.

https://www.rtu.lv/lv/universitate/masu-medijiem/zinas/atvert/ ekonomikas-ministrs-iepazistas-ar-rtu-petijumiem-energetika

\section{October 19-23}

To update the discussion on the observance of ethics in the academic environment, RTU hosts Academic Integrity Week, in which, marking the International Day of Ethics and the Day for Combating Commissioned Works, the RTU Glossary for Academic Integrity Terms is opened.

https://www.rtu.lv/lv/universitate/masu-medijiem/zinas/atvert/ rtu-izdod-akademiska-godiguma-terminu-vardnicu

\section{October 23-25}

Students of (IDT) of FMSAC win the main prizes in the competition of schools and universities «Design Arena 2020». In the category «Best Design Student of the Year» Marta Cimdina wins 1st place; 2nd place Svens Martulevs. 1st place in the category «Environmental design» wins Renāte Santa Gruzninga; 3rd place - Elinna Leiba-Lipsne. 3rd place in the category of bachelor's theses in the category «Design research» wins Ilmārs Bērziñ̌s; R. S. Gruzninga wins the 3rd place in this category in the master's thesis section.

https://www.rtu.lv/lv/universitate/masu-medijiem/zinas/atvert/ rtu-studentiem-pamatigs-balvu-klasts-konkursa-dizaina-arena-2020 


\section{October 26}

With the decision of the Senate of RTU (Minutes No. 643):

- Rolf Qvenild, Associate Professor at the University of South-Eastern Norway, has been awarded the title of RTU Honorary Member;

- Professor Jānis Mazais has been awarded the title of RTU Professor Emeritus;

- $\quad$ by merging the Department of Railway Automatics and Telematics of the Transport Institute and the Department of Railway Transport of FMETA, the Department of Railway Engineering has been established.

\section{October 30}

FCSIT Professor, politician and former Minister of Education and Science (2002-2004; 2016-2018) Kârlis Šadurskis is awarded the Order of the Three Stars for special merits for the benefit of the State Latvia.

https://www.president.lv/lv/valsts-apbalvojumi/triju-zvaigznu-ordenis/jaunakiepieskirtie-apbalvojumi\#gsc.tab=0

\section{In October}

For the first time the prestigious Web of Science database indexed two RTU scientific monographs - «From Airplanes to Rockets - Friedrich Zander and Early Aviation in Riga and «Ernst Nauck (1819 -1875). The First Director of Riga Polytechnicum». Both monographs have been prepared for publication at RTU RCEH.

https://www.rtu.lv/lv/universitate/masu-medijiem/zinas/atvert/ prestizaja-datubaze-web-of-science-indeksetas-divas-rtu-zinatniskas-monografijas RTU receives an invitation to join the international association «T.I.M.E.» (Top International Managers for Engineering).

https://www.rtu.lv/lv/universitate/masu-medijiem/zinas/atvert/rtu-sanemuzaicinajumu-pievienoties-prestizajai-starptautiskajai-asociacijai-t-i-m-e?fbclid=I wAR1AyvTw2psROxDth47LEtnIdUOnBaCHkIT8TKcV5diRxIwUVByGTZxLjEY

The Baltic Management Development Association grants an award for innovation to the RTU Faculty of Engineering Economics and Management (FEEM), evaluating the implemented interdisciplinary approach in entrepreneurship education.

https://www.rtu.lv/lv/universitate/masu-medijiem/zinas/atvert/rtuinzenierekonomikas-un-vadibas-fakultate-inovativaka-fakultate-baltijas-jurasregiona 
In the RTU international rating «Times Higher Education (THE) World University Rankings 2021 by Subject» in the field of engineering and computer science studies, it receives the highest rating in Latvia.

https://www.rtu.lv/lv/universitate/masu-medijiem/zinas/atvert/rtu-timeshigher-education-reitinga-inzenierzinatnu-un-datorzinatnes-studiju-joma-sanemaugstako-vertejumu-latvija

\section{November 16}

RTU is the first higher education institution in the Baltic States to sign the Latvian Diversity Charter, thus confirming that it supports diversity and equal opportunities in the study and work environment.

https://www.rtu.lv/lv/universitate/masu-medijiem/zinas/atvert/ rtu-parakstis-dazadibas-hartu-apnemoties-ieverot-dazadibas-vadibas-principus

\section{November 20}

The Dean of FCSIT, Professor Agris Nikitenko, receives the Certificate of Honour of the National Guard of the RL.

https://www.rtu.lv/lv/universitate/masu-medijiem/zinas/atvert/rtu-profesoramagrim-nikitenko-pasniedz-latvijas-republikas-zemessardzes-goda-rakstu

\section{November 26}

At the general meeting of the LAS, FMSAC Professor Jānis Ločs, has been elected an executive member (academician) of the LAS.

https://www.rtu.lv/lv/universitate/masu-medijiem/zinas/atvert/ profesors-janis-locs-ievelets-par-latvijas-zinatnu-akademijas-isteno-locekli

\section{November 27}

President Egils Levits remotely greets RTU EHS pupils and graduates Džonatans Miks Melgalvis, Daniels Stabulis, Edvards Mikelis Mežciems, Filips Ëcis, Kārlis Šusters and Atis Krebss - and their teachers - Lïga Kamola (economics), Agra Lipsberga (geography), Laura Fjodorova (chemistry) and Andrejs Liepiňš (programming) - on achievements in international training Olympiads.

https://www.izv.lv/2020/11/valsts-prezidents-sveic-rtu-inzenierzinatnuvidusskolas-skolenus-un-skolotajus/?fbclid=IwAR3q4ITcGqNp9YEj89C s5F_OlLEg_l4LO78faZ44mIRIqokUEv5ykykPh3g

\section{November 30}

With the decision of the Senate of RTU (Minutes No. 644):

- Professor Oskars Krievs is confirmed as the Dean of FEEE;

- RTU Cooperation Coordination Centre has been established. 


\section{In November}

For the fifth year in a row, FEEM and RTU Riga Business School are included in the ranking of the world's best business schools «Eduniversal» in the four-palm league, which means a particularly high academic level, excellent quality and strong international influence in business and management education.

https://www.rtu.lv/lv/universitate/masu-medijiem/zinas/atvert/ rtu-biznesa-un-vadibas-izglitibai-nemainigi-augsts-starptautisks-novertejums

FCE Professor Egils Dzelzitis is awarded the title of Honorary Citizen of Ogre for his contribution to the progress of the new building project of the Ogre Central Library, the development of the energy construction industry and its professional education in Latvia, as well as the achievements in increasing energy efficiency in heating systems. http://www.ogrenet.lv/ogre/aktualitates/48437/

RTU is the only Latvian university education institution to enter the section of the international rating «World's Universities with Real Impact» (WURI), which evaluates the university's contribution to the promotion of entrepreneurship.

https://lvportals.lv/dienaskartiba/322340-rtu-vieniga-no-latvijas-ieklust-reitingakura-novertets-universitates-ieguldijums-uznemejspeju-veicinasana-2020

\section{December 6}

FEEM student, Latvian bobsleigh pilot Dāvis Kaufmanis wins third place in the second stage of the European Cup in Germany.

https://www.delfi.lv/sports/news/winter_sports/bobsleigh/

bobsleja-pilots-kaufmanis-eiropas-kausa-izcina-treso-vietu.d?id=52729959

\section{December 15}

The Latvian government decides on the establishment of a laboratory for personal protective equipment for accredited testing. The new laboratory will be established on the basis of RTU, with the involvement of RSU, especially the Institute of Occupational Safety and Environmental Health, the Latvian Biomedical Research and Study Centre, as well as the Institute of Food Safety, Animal Health and Environment «Bior».

https://www.delfi.lv/news/national/politics/latvija-veidos-laboratorijuindividualo-aizsardzibas-lidzeklu-akreditetai-testesanai.d?id=52760479\&fbclid $=I \mathrm{w}$ AR1u1HwZS3bwsLyGqoZiiiRoYYLW2gOW-2iLOFXfPpkEDsjOP3Kxd4uBoY4 


\section{December 19-21}

RTU team wins second place in Latvian online sports championship in the bridge.

https://www.rtu.lv/lv/sports/sporta-centra-jaunumi/atvert/rtu-komandaiotra-vieta-latvijas-tiessaistes-cempionata-sporta-bridza?fbclid=IwAR1foh7amtGmDfqLMc_HfbuNTHDJPPvw6FNHVwgvnRDJfBieq4hHrYP4Zo

\section{December 21}

RTU Strategy 2021-2025 was approved by the decision of the RTU Senate (Minutes No. 645).

\section{December 22}

Marta Cimdina, a 1st year master's degree student of FMSAC IDT, wins 1st place in the competition of young fashion designers «Fashion Manifestation», winning the right to represent Latvia with her collection «Introvert Extraversion» in the competition «International Young Designers Contest 2021» in Kiev, Ukraine next year in July. https://www.delfi.lv/kultura/news/culturenvironment/foto-jauno-dizainerukonkurss-modes-manifestacija-labaka-kolekcija-martai-cimdinai.d?id=52786009

\section{December 23}

For achievements in international subject Olympiads, the Cabinet of Ministers awards prizes to RTU EHS pupils, graduates and their teachers: to EHS 12th grade pupil Džonatans Miks Melgalvis; to EHS graduate, FMSAC 1st year student Edvards Mikelis Mežciems; to EHS graduate, FMSAC 1st year student Filips É cis; to EHS graduate, 1st year student of the University of Cambridge Kārlis Šusters, as well as to teachers Laura Fjodorova (chemistry) and Virginnija Vìtola (physics).

https://www.rtu.lv/lv/universitate/masu-medijiem/zinas/atvert/rtuinzenierzinatnu-vidusskolas-skoleni-absolventi-un-pedagogi-sanem-ministrukabineta-balvas?fbclid=IwAR2t7GdoKWR1AAqreMtU1EYKEe60y1jiUeNj8 $5 N e_{-}$mHQV4YAIgkgdgQN28A

JSC «Latvenergo» and LAS Annual Awards in Energy receive FEEE young scientists and graduate: Leading Researcher of the Institute of Energy Systems and Environment (IESE) Dr. sc. ing. Mikelis Dzirkevics; Research Assistant of the Institute of Power Engineering (IPE) Dr. sc. ing. Romāns Olekšijs; researchers of IPE Dr. sc. ing. Zane Broka, Dr. sc. ing. Kārlis Baltputnis and Dr. sc. ing. Ivars Zālìtis; the promotion awards are given to the Research Assistant of the Institute of Industrial Electronics and Electrical Engineering Dr. sc. ing. Jānis Mārks and FEEE graduate Dr. sc. ing. Dmitrijs Sobolevskis.

https://www.rtu.lv/lv/universitate/masu-medijiem/zinas/atvert/rtu-jauniezinatnieki-sanem-latvenergo-un-latvijas-zinatnu-akademijas-gada-balvasenergetika 


\section{In December}

Latvian fashion artist, FMSAC IDT graduate Anna Elizabete Kasparsone is included in the exhibition Global Qipao Invitational Exhibition 2020, which takes place from autumn 2020 to October 2021 in Hangzhou, China.

https://www.diena.lv/raksts/kd/maksla/latvijas-modesmaksliniece-anna-elizabete-kasparsone-ieklauta-starptautiskaizstade-kina-14252213?fbclid=IwAR2T9Mhxj2-TsJgzAa6aUZ_

SeWbhmuORDAYFN8rqwRPfUfHnje8ZxIRKnnO

RTU students in the study year 2020/2021 receives the largest number of Sports Scholarships of the Latvian Sports Federations Council in the study year in comparison with other Latvian higher education institutions.

https://www.rtu.lv/lv/universitate/masu-medijiem/zinas/atvert/rtu-studejosiesportisti-sanem-stipendijas-akademiskas-un-sportiskas-izaugsmes-sekmesanai

For the first time in the reputation assessment of the world's best business schools «Eduniversal» FEEM and RTU Riga Business School receive the highest rating in Latvia.

https://www.rtu.lv/lv/universitate/masu-medijiem/zinas/atvert/rtuinzenierekonomikas-un-vadibas-fakultate-prestizaka-biznesa-izglitibas-iestadelatvija

Significantly increasing its position in the green policy and sustainability rating «GreenMetric», RTU is recognized as one of the 60 greenest universities in the world.

https://www.rtu.lv/lv/universitate/masu-medijiem/zinas/atvert/ rtu-atzita-par-vienu-no-60-zalakajam-universitatem-pasaule

In the international rating «RUR World University Ranking», RTU, compared to last year, increases its performance in several positions. RTU is still the only Latvian higher education institution included in this rating.

https://www.rtu.lv/lv/universitate/masu-medijiem/zinas/atvert/rtu-kapinajusisavu-sniegumu-starptautiskaja-reitinga-rur-world-university-ranking

FMSAC Professor Valdis Kampars is awarded the World Intellectual Property Organization (WIPO) «Medal for Inventors» for significant contribution and innovative work in creating inventions, especially in the field of biofuels.

https://www.rtu.lv/lv/universitate/masu-medijiem/zinas/atvert/profesoravalda-kampara-ieguldijums-zinatne-novertets-ar-pasaules-intelektuala-ipasumaorganizacijas-medalu 
RTU is highly valued in cooperation with employers in «QS ECCA 2021» ranking.

https://www.rtu.lv/lv/universitate/masu-medijiem/zinas/atvert/

rtu-reitinga-qs-ecca-2021-visaugstak-noverteta-sadarbiba-ar-darba-devejiem

In 2020, RTU ranked 56th place in the green policy and sustainability

rating «GreenMetric».

https://labsoflatvia.com/aktuali/rtu-greenmetric-2020?fbclid=IwAR1FMUdIAPiFr

kIKOBOq5dO7qncQzyWHQXyYPSPRzdYFIr03TPsauDQMW5E

\section{1}

\section{January 5}

Taking into account the amendments to the Covid-19 Infection Spread Management Law adopted by the Saeima of the Republic of Latvia on 18 December 2020, which give the right to higher education institutions to hold elections of key decision-making bodies by 1 May 2021, RTU Constitutional Assembly makes a decision (Minutes No. 31) to postpone the elections of the RTU Constitutional Assembly, Academic Arbitration Court, Senate and RTU Rector until 31 December 2021. Until the date of entry into force of the powers of the newly elected main decision-making bodies of the University, the powers of the said elected institutions shall be fulfilled, and until the date of entry into force of the powers of the new Rector, the current Rector and existing Vice-Rectors shall continue their work.

\section{January 15}

During the European Cup in bobsleigh on the Igls track in Innsbruck (Austria), the four of the piloted by Latvian bobsleigh player Dãvis Kaufmanis, a student of the FEEM, wins the high 3rd place.

https://bobslejs.lv/raksts/kaufmanis-pirmo-reizi-uz-pjedestalacetriniekos?fbclid=IwAR2k4Wrd_YAie1-HTm89_bd5H3vxlLaPjvZ7iNywN2b0oz1_ xmqr3hW3a-M

\section{January 19}

LAS awards the Award named by Emilija Gudriniece in chemistry to Jānis Mikelis Zakis, the Research Assistant at the FMSAC Institute of Technology of Organic Chemistry.

https://www.rtu.lv/lv/universitate/masu-medijiem/zinas/atvert/emilijasgudrinieces-vardbalvu-kimija-pieskir-rtu-jaunajam-zinatniekam-janim-mikelimzakim 


\section{January 21}

The Saeima of the Republic of Latvia grants Latvian citizenship to the patron of RTU, co-owner and Chairman of the Board of CEO «Mikro Tik» John Martin Tully.

https://www.rtu.lv/lv/attistibasfonds/fonds-par-mums/zinas-1/atvert/ apsveicam-dzonu-martinu-talliju-ar-ieguto-latvijas-pilsonibu

\section{January 27}

RTU management, students, lecturers and scientists meet online with the Minister of Education and Science Ilga Šuplinska and the Director of the Department of Higher Education, Science and Innovation of the Ministry of Education and Science (MES) Dmitrijs Stepanovs to discuss higher (university) education and science issues.

Celebrating the 100th Anniversary of Polish-Latvian diplomatic relations, RTU Rector Academician Leonīds Ribickis receives a congratulatory letter and a commemorative medal from the Ambassador of the Republic of Poland to Latvia, Monika Michaliszyn.

\section{In January}

For the achievements in science in 2020, the LAS President's Certificates of Recognition are received by three groups of scientists from FMSAC: Associate Professor Andris Šutka, Leading Researcher Kaspars Mālnieks, Researcher Linards Lapčinskis and their partners at the University of Melbourne (Australia); Professor Valdis Kampars, Leading Researcher Zane Ābelniece, Leading Researcher Kristīne Lazdoviča, Researcher Lauma Laipniece, Research Assistant Agija Stanke, Researcher Rūta Kampare, Assistant Professor Elīna Sīle, Leading Researcher Modris Roze; a joint team of FMSAC, the Institute of Solid State Physics of the University of Latvia (UL) and the Latvian Institute of Organic Synthesis - Leading Researcher Irina Novosjolova, Leading Researcher Kaspars Traskovskis, Researcher Armands Sebris, Research Assistant Jānis Mikelis Zakis, Research Assistant Andris Jeminejs, Professor Érika Bizdēna, Professor Valdis Kokars, Professor Māris Turks, Mg. chem. Kristers Ozols, Mg. chem. Dace Cīrule, Mg. phys. Natālija Tetervenoka and Dr. phys. Anatolijs Mišnovs. https://www.rtu.lv/lv/universitate/masu-medijiem/zinas/atvert/rtu-kimiki-sanemlza-prezidenta-atzinibas-rakstus-par-sasniegumiem-zinatne-2020-gada

\section{February 1}

Congratulating the most active users of the e-signature of 2020, the Latvian State Radio and Television Center awards the award «eSignature 
Champion 2020» and a diploma for the obtained third place to RTU. In the first place - the portal Latvija.lv, in the second place - the State Revenue Service.

https://www.eparaksts.lv/lv/par_mums/Jaunumi/ eParaksts_tiek_lietots_videji_26_027_reizes_diena

\section{February 5}

Gathering students, lecturers, representatives of RTU management and faculties online, the winners of the RTU Student Parliament Annual Award 2020 are solemnly named and congratulated online.

https://www.rtu.lv/lv/rtusp/par-rtusp/sp-zinas/atvert/pgb2020-rezultati

\section{February 6}

RTU wins the Year Award of the Students Union of Latvia in two nominations: FET doctoral student Jānis Braunfelds has been recognized as the "Young Scientist of the Year 2020»; in the nomination «Innovation of the Year», the award is received by the impact program «CrisisLab» initiated by RTU, created in cooperation with the UL, the Latvian Maritime Academy, the University of Liepaja and Ventspils University of Applied Science.

https://www.lsa.lv/notikusi-ikgadeja-lsa-gada-balva-par-studentu-lietu-atzitaakcija-gribustudet/

\section{February 20}

In the European Cup overall, FEEM student, Latvian bobsleigh pilot Dāvis Kaufmanis win the 2nd place in doubles.

https://www.facebook.com/LVbsf/posts/3672047199577021

\section{February 26}

RTU Open Day takes place online.

https://www.rtu.lv/lv/universitate/masu-medijiem/zinas/atvert/

rtu-toposos-studentus-aicina-uz-atverto-durvju-dienu-tiessaiste

\section{February 26-28}

RTU students win medals in the international swimming competition «Latvian Open 2021», which is also an officially recognized qualification competition of the Fédération internationale de natation (FINA) for the XXXII Summer Olympic Games in Tokyo. Daniils Bobrovs wins two silver medals (100 m and 200 m breaststroke), while Artūrs Markovs - a bronze medal (400 m freestyle).

https://www.rtu.lv/lv/sports/sporta-centra-jaunumi/atvert/rtu-peldetajiemstarptautiskajas-sacensibas-sudraba-un-bronzas-medalas-atseviskas-disciplinas 


\section{March 1}

FA graduate Una Île becomes a laureate of the Latvian Regional Architecture Prize of Professor Ivars Strautmanis.

https://www.rtu.lv/lv/universitate/masu-medijiem/zinas/atvert/profesora-ivarastrautmana-premiju-sanem-arhitekturas-fakultates-absolvente-una-ile

\section{March 4}

RTU Career Day takes place online.

https://www.rtu.lv/lv/universitate/masu-medijiem/zinas/atvert/ rtu-aicina-jauniesus-piedalities-virtualaja-karjeras-diena

\section{March 5}

RTU receives an award from the Ministry of Defence in the nomination «Educational Institution «Educator for the National Guard»».

\section{March 26}

For the first time in the history of RTU, doctoral student Brigita Dalecka is simultaneously defending her doctoral dissertation in Latvia, RTU, and in Sweden, at the HTH Royal Institute of Technology in Stockholm.

https://www.rtu.lv/lv/universitate/masu-medijiem/zinas/atvert/ pirmo-reizi-rtu-vesture-doktorante-aizstaves-promocijas-darbu-latvija-un-zviedrija

His Excellency Ambassador of the Italian Republic Stefano Maria Taliani de Marchio held a meeting with the Deputy Rector for International Academic Cooperation and Studies of Riga Technical University, Igors Tipāns, and Project Manager of International Cooperation and Foreign Students Department (ICFSD), Ériks Badamšins. During the meeting, among the issues under consideration, significant importance was given to the possible establishment of Italian language courses at RTU (to RTU students and staff), which would take place with the financial support of the Ministry of Foreign Affairs and International Cooperation of Italy.

https://www.rtu.lv/en/university/for-mass-media/news/open/icfsdand-the-ambassador-of-italy-to-latvia-discuss-the-establishment-ofitalian-language-courses-at-rtu?fbclid=IwAR10h52RyuRHxuoafoAYV8o G8q-y0X5Lw_kePwqg2zYB4t9ZqxSt2UiFHxM

\section{In March}

RTU improves its position in the prestigious international rating «QS World University Rankings by Subject 2021», ranking 201-220th place among the best universities in architecture, as well as ranks in engineering and technology, entering 401-450th among the best universities in the world.

https://www.rtu.lv/lv/universitate/masu-medijiem/zinas/atvert/ rtu-nostabilizejas-reitinga-starp-pasaules-vadosajam-inzenierzinatnu-augstskolam 
RTU students Daniils Bobrovs (FEEM) and Artūrs Markovs (FMETA), as well as graduate Girts Feldbergs, win several medals in the swimming championship of the Baltic States.

https://www.rtu.lv/lv/sports/sporta-centra-jaunumi/atvert/rtu-peldetajivairakkart-kapj-uz-goda-pjedestala-baltijas-valstu-cempionata?fbclid=IwAR0Jg3D H7sJYcKNDC_A3jTtuk49sgyef7Bcrmwf8ekrhq8P8rzlSLhliGwM

RTU ranks 251-300th place in the ranking of universities in emerging economies «The Emerging Economies University Rankigs 2021» by the world's most prestigious rating agencies «Times Higher Education» (THE).

https://www.rtu.lv/lv/universitate/masu-medijiem/zinas/atvert/starptautiskajajaunas-ekonomikas-valstu-reitinga-augstu-noverte-rtu-starptautisko-sadarbibuun-ienakumus-no-industrijas

RTU has been awarded the Erasmus University Charter (ECHE - Erasmus Higher Education Charter) for the second time for the «Erasmus+» program period from 2021 to 2027.

https://www.rtu.lv/en/university/for-mass-media/news/open/

riga-technical-university-has-been-awarded-erasmus-charter-for-higher-education

\section{April 13}

The first 3D concrete printing scientific laboratory in the Baltics is opened, created by RTU in cooperation with Ltd. «Sakret».

https://www.rtu.lv/lv/universitate/masu-medijiem/zinas/atvert/

rtu-partneriba-ar-sakret-izveido-baltija-pirmo-3d-betona-drukasanas-laboratoriju

\section{April 19}

RTU Rector Academician Leonīds Ribickis and Minister of Environmental Protection and Regional Development Artūrs Toms Plešs sign a memorandum of cooperation online on the exchange of information, skills and experience.

https://lvportals.lv/dienaskartiba/327181-varam-sadarbosies-ar-lu-un-rtudigitalo-prasmju-integracijai-akademiskaja-vide-2021

\section{April 19-30}

An online event «Connect to RTU!» is taking place, which allows secondary school pupils to feel in the skin of RTU students and learn about study opportunities. Each day is dedicated to one of the nine faculties of RTU.

https://www.rtu.lv/lv/nac-studet/aktualitates-berniem-un-jauniesiem/ piesledzies-rtu 


\section{April 20}

The President of Latvia Egils Levits and the Chapter of the Order decide: for special merits for the benefit of the State of Latvia to award the Order of the Three Stars to the Dean of FA, Professor Uǵis Bratuškins, by appointing the Professor as an Officer of the Order of the Three Stars; to award the Cross of Recognition to Professor Alida Zigmunde, a long-term researcher of RTU history, by appointing the Professor as the Commander of the Cross of Recognition.

https://www.rtu.lv/lv/universitate/masu-medijiem/zinas/atvert/rtu-arhitekturasfakultates-dekans-ugis-bratuskins-un-inzenierzinatnu-vestures-petniece-alidazigmunde-sanems-augstakos-valsts-apbalvojumus

\section{April 21}

RTU Rector Academician Leonìds Ribickis signs the updated «Magna Charta Universitatum 2020».

https://www.youtube.com/watch?v=j923TMRXHhA\&t=9s

\section{April 22}

RTU University of Children and Youth organizes the first international lesson for Latvian and Danish pupils, giving a start to the project «Phereclos». Its aim is to promote an open school culture in Latvia, STEM (Science, Technology, Engineering and Mathematics) access to education and the involvement of young people in science.

https://www.rtu.lv/lv/universitate/masu-medijiem/zinas/atvert/ rtu-sak-starptautisku-projektu-lai-veicinatu-stem-izglitibas-pieejamibu-berniem

\section{April 23}

RTU is visited by the Ambassador Extraordinary and Plenipotentiary of the Italian Republic to Latvia Stefano Maria Taliani de Marchio.

https://www.rtu.lv/lv/universitate/masu-medijiem/zinas/atvert/ italijas-vestnieks-latvija-iepazistas-ar-rtu-studiju-un-zinatnes-aktivitatem

\section{April 29}

The artistic Director and choreographer of RTU Folk Dance Ensemble «Vektors» Dagmāra Bārbale at the Dance Prize Awards Ceremony in the category «Dejas notikums» (Dance Event) receives the LSM.lv voters' sympathy award for the video work «Saules zìmē rotāties» (Decorate in the Sun Sign).

https://www.rtu.lv/lv/kultura/par-mums-kultura/jaunumi-kultura/atvert/ sveiciens-visiem-dejotajiem-un-dejas-makslas-turetajiem-rtu-un-latvijastarptautiskaja-dejas-diena 


\section{In April}

Student of the Faculty of E-Learning Technologies and Humanities (FETH) Heinrihs Cielavs wins the annual competition of the language company «Skrivanek Baltic» for the students of the universities of Latvia «The best young translator 2021». RTU student Maija Pokule wins third place in the competition.

https://www.rtu.lv/lv/universitate/masu-medijiem/zinas/atvert/ rtu-students-heinrihs-cielavs-atzits-par-2021-gada-labako-jauno-tulkotaju

RTU in rating «Impact Rankings 2021» it is recognized as the 64th best university in the world that fights against climate change. The ranking includes 1115 universities from 94 countries.

https://www.rtu.lv/lv/universitate/masu-medijiem/zinas/atvert/ rtu-reitinga-impact-rankings-2021-atzita-par-64-pasaule-labakouniveristati-kas-cinas-pret-klimata-parmainam?fbclid=IwAR1D2vPtweFfdIn N4I-SnabecpX9NZZOi_ibZBEg_yvET9QiO2BqBZLaEOA

For the first time, all FEEM master's study programs are included in the prestigious «Eduniversal Best Masters Ranking» of the world's best business schools, confirming the international competitiveness and high employers' assessment of the education offered by RTU.

https://www.rtu.lv/lv/universitate/masu-medijiem/zinas/atvert/visas-rtu-biznesaun-vadibas-izglitibas-magistra-studiju-programmas-ieklust-pasaules-top

Four RTU students - three bobsleighers Lauris Kaufmanis (FCE), Dāvis Kaufmanis, Ralfs Bērziņš and skeleton racer Dārta Estere Zunte (all FEEM students) - are included in the Latvian Olympic team, which will participate in the Winter Olympic Games in Beijing, China in February 2022.

https://www.rtu.lv/lv/sports/sporta-centra-jaunumi/atvert/cetri-rtu-studentiieklauti-latvijas-olimpiskaja-vieniba-kas-startes-ziemas-olimpiskajas-speles-pekina

\section{May 2}

FEEM student Aneta Tarasova, who was previously the Head of the Department of External Relations of RTU SP, is elected the President of the RTU SP.

https://www.rtu.lv/lv/rtusp/par-rtusp/sp-zinas/atvert/ arkartas-velesanas-ieveleti-atlikusie-valdes-locekli

\section{May 3}

FCSIT celebrates its 60th anniversary. 


\section{May 5}

RTU Business School Director Jānis Grēviņš becomes a Member of the Council of the European Institute of Innovation and Technology.

https://www.rtu.lv/lv/universitate/masu-medijiem/zinas/atvert/

rtu-rigas-biznesa-skolas-direktors-grevins-klust-par-eit-direktoru-padomes-locekli

\section{May 13-14}

RTU students pick the laurels of victory in international swimming competitions «Latvian qualification meet»: Daniils Bobrovs (FMETA) wins 200 m swimming in the breaststroke; Artūrs Markovs (FEEM) wins a gold medal in the $200 \mathrm{~m}$ and a silver medal in the $400 \mathrm{~m}$ freestyle; Atis Āre (FCE) wins a bronze medal at a distance of $50 \mathrm{~m}$ in backstroke; RTU graduate Girts Fedbergs, on the other hand, wins a gold medal in the $100 \mathrm{~m}$ backstroke and wins the overall standings.

https://www.rtu.lv/lv/sports/sporta-centra-jaunumi/atvert/rtu-peldetaji-izcinagodalgas-starptautiskajas-sacensibas-kipsalas-peldbaseina?fbclid=IwAROLHZ_ GZsTH9JeJje1y1Bh6-kZN8ZcY_TtjyXulEp9GnKSS5iarnHfTDJO

\section{May 15-16}

FEEM 2nd year student Artūrs Rinkevičs in a duet with Ardis Daniels Bedritis wins a silver medal in the European U-22 beach volleyball championship.

https://www.rtu.lv/lv/sports/sporta-centra-jaunumi/atvert/rtupludmales-volejbolistam-sudrabs-eiropas-u-22-cempionata?fbclid=IwAR15p2Ps9WLI3sW1-MXH5RrVBOTSSEEEfd1owOLYSi9OriXTVT7CrJN 110

\section{May 21}

A digital forum «Does the Latvian education system achieve its goal» is being organized by the Saeima Education, Culture and Science Commission, the Ministry of Education and Science and RTU, where expert discussions on linking higher and vocational education with the labour market are taking place. Each day of the forum is dedicated to a specific topic - primary and secondary education, higher and vocational education, as well as adult education and retraining (the first discussion on 21 May; the second discussion on 28 May; the third discussion on 4 June).

https://www.rtu.lv/lv/universitate/masu-medijiem/zinas/atvert/ foruma-izglitibas-sistema-un-darba-tirgus-saturiskie-materiali

\section{May 28}

In gratitude for the successful cooperation, the Commander of the Naval Forces of National Armed Forces, Captain Kaspars Zelčs, presents a Letter 
of Recognition to the Director of RTU Liepāja Centre for Studies and Research Mārcis Priedītis.

https://www.facebook.com/Latvijasjurasspeki

\section{May 28-29}

For the tenth year in a row, RTU is hosting the «10th International Doctoral School of Energy Conversion and Saving Technologies». This year, school activities take place online.

https://ieei.rtu.lv/ids-ecst/

\section{May 31}

The Senate of RTU makes a decision (Minutes No. 650):

- to make amendments to the RTU Regulations on Awards and Diplomas approved at the Senate of RTU meeting on 28 October 2019 (Minutes No. 633), supplementing the range of awards to be awarded by the Senate decision with the award «RTU Honorary Professor» awarded to retired professors for outstanding pedagogical, scientific and organizational activities at RTU during at least the previous 10 years, and to approve the regulations «On Awarding the Title of Honorary Professor of RTU»;

- to liquidate the Research and Professional Competence Centre of Road Transport of the FMETA Institute of Transport.

\section{In May}

The Secretary-General of the United Nations (UN), Antonio Guterres, has approved a group of 10 outstanding scientists and researchers who will advise on how to use science, technology and innovation to accelerate the achievement of the UN's Sustainable Development Goals. Among them is also RTU Vice-Rector for Research Academician Tālis Juhna.

https://www.rtu.lv/lv/universitate/masu-medijiem/zinas/atvert/rtu-prorektorstalis-juhna-konsultes-ano-ka-vairot-tehnologiju-potenciala-izmantosanu\%C2\%AO

FMETA receives a valuable gift from the company «Instro»- measuring instruments for the Department of Mechanical Engineering and Mechatronics worth almost eight thousand euros.

https://www.rtu.lv/lv/universitate/masu-medijiem/zinas/atvert/uznemumsinstro-davina-jaunus-merinstrumentus-rtu-masinbuves-un-mehatronikas-katedrai

Nadina Anija Poga, a graduate of the IDT of FMSAC, develops new design uniforms for Liepāja public transport controllers.

https://www.rekurzeme.lv/vietejas-zinas/liepaja/liepajas-sabiedriska-transportakontrolieriem-bus-jauna-dizaina-formasterpi-153311 
RTU EHS team wins the Baltic Biomaterials Centre of Excellence (BBCE) erudition competition for pupils «BIO-GO-Higher», winning a trip to Switzerland and the opportunity to participate in biomaterials research at the AO Research Institute Davos.

https://www.izv.lv/2021/05/

rtu-izv-komanda-uzvar-erudicijas-konkursa-bio-go-higher/

\section{June 1}

RTU Leading Researcher Inga Lašenko receives the Award of the Latvian Security and Defence Industries Federation 2021 in education and research.

https://www.rtu.lv/lv/mtaf/par-mums-mtaf/mtaf-zinas/atvert/ rtu_vadosa_petniece_sanema_balvu

\section{June 10}

The annual fashion show of the students of the FMSAC IDT takes place, in which the students' works are decorated in an innovative format - in a special fashion short film cycle.

https://www.delfi.lv/kultura/news/culturenvironment/foto-modes-diplomdarbiieskats-rtu-dizaina-tehnologiju-studentu-kolekcijas.d?id=53262707

\section{June 22}

RTU is visited by the President of the European Commission Ursula von der Leyen and the Prime Minister of the RL Krišjānis Karinšs. The officials meet with the RTU management, visit the Student Campus in Kiipsala, get acquainted with the innovations created by scientists and give a press conference.

https://www.rtu.lv/lv/universitate/masu-medijiem/zinas/atvert/ ek-priekssedetaja-rtu-iepazisies-ar-zinatnieku-raditajam-zalajam-tehnologijam

\section{June 26-27}

RTU athletes win the title of Latvian champion in athletics. https://www.rtu.lv/lv/sports/sporta-centra-jaunumi/atvert/rtu-sportisti-izcinalatvijas-cempiona-titulu-vieglatletika?fbclid=IwAR2CMqjbgd6zO69KexYuE118cJEn oGwNIrJX15ylSAHPw2zgU3Xq2A0D8hQ

\section{June 28}

The Senate of RTU makes a decision (Minutes No. 651):

- to unite the Institute of Silicate Materials, Institute of Inorganic Chemistry and Research Laboratory of Functional Materials Technologies of FMSAC and to establish Institute of Materials and Surface Engineering and to approve the regulations of the newly established institute; 
- $\quad$ to change the name of the Institute of Construction and Reconstruction of RTU FCE to «Institute of Structural Engineering» and stipulate that the decision enters into force on

1 September 2021.

\section{In June}

RTU Rector Academician Leonìds Ribickis receives the Award of the Polish Association of Electrical Engineers - the Medal of Mikhail DolivoDobrovolsky for achievements in electrical engineering.

RTU is included in international rating «QS World University Rankings 2022» taking 751-800th place and this indicator is the highest of the evaluation results of the three Latvian universities included in the rating - RTU, RSU and the UL.

https://www.rtu.lv/lv/universitate/masu-medijiem/zinas/atvert/ rtu-latvija-saglaba-liderpozicijas-prestizaja-qs-world-university-rankings-1

For the fourth year, RTU is included in the highest or platinum category of the «Sustainability Index».

https://www.rtu.lv/lv/universitate/masu-medijiem/zinas/atvert/ rtu-saglaba-savas-pozicijas-ilgtspejas-indeksa-platina-kategorija

\section{July 1}

Professor of FA Dr. arch. Sandra Treija receives a Letter of Recognition from the Ministry of Education and Science of the Republic of Latvia for outstanding achievements in developing higher education in architecture in Latvia.

https://lvportals.lv/dienaskartiba/330025-dr-arch-sandrai-treijai-pasniedzatzinibas-rakstu-par-sasniegumiem-attistot-augstako-izglitibu-arhitektura-2021

\section{July 2}

RTU Rector Academician Leonīds Ribickis signs a cooperation agreement with the European Space Agency on the establishment of ESA_lab@RTU, strengthening the university's competence in the field of space technologies and promoting the growth of space and related industries.

https://www.rtu.lv/lv/universitate/masu-medijiem/zinas/atvert/rtu-parakstisligumu-ar-eiropas-kosmosa-agenturu?fbclid=IwAR18-MODM2vAIUakVNIlBPtIFxH4 2maKvPkvEa-Syd0yPPSS6GRhRN42fgs

For the tenth year in a row, RTU is recognized as the most recommended higher education institution in Latvia by employers. 
The fourth RTU EHS graduation is taking place.

https://www.izv.lv/2021/07/

rtu-inzenierzinatnu-vidusskola-nosvinets-ceturtais-izlaidums/

\section{July 3 and 4}

For the first time in the history of the Baltic States, three «EIT Food» centres in the region - «AgriFood Lithuania DIH», RTU and Tartu Biotechnology Park - are jointly organizing an international online hackathon, «HACK DigitalSea'21», to find solutions for sustainable aquaculture development in the Baltic Sea region.

https://www.rtu.lv/lv/universitate/masu-medijiem/zinas/atvert/ notiks-pirmais-digitalas-juras-hakatons-baltijas-valstis

\section{July 8}

The time capsule is laid in the foundations of the research and training hangar of Institute of Aeronautics of FMETA, at 8 Kjipsalas Street, on the side of Zunda Canal.

https://www.rtu.lv/lv/universitate/masu-medijiem/zinas/atvert/iemurespamatakmeni-angaram-kura-rtu-zinatnieki-un-studenti-attistis-aeronautikastehnologijas

Agrita Krievina-Silina, Practical Assistant Professor at the FMSAC IDT, receives the award «Par ieguldijumu. Sieviete - dizaina veicinātāja 2020» (For Investment. Woman - Design Promoter 2020) in the competitionforum «Sieviete arhitektūrā, būvniecībā un dizainā» (Woman in Architecture, Construction and Design).

https://www.buvniekupadome.lv/konkurss/konkursa-foruma-sieviete-arhitekturabuvnieciba-dizaina-2020-rezultati/?fbclid=IwAR1Lin2PsmrMbvDKmwhUfAyeOkOIB 1ASJKPCXVY7DCRIVMGAX3UTCELO-UM

\section{July 9}

The traveling exhibition «Jaunie arhitekti - Latvijai» (Young Architects for Latvia) created by FA is opened in Césis Central Library. The exhibition is the final event in the cycle of events celebrating the 150th anniversary of the education of architects.

https://www.rtu.lv/lv/af/par-mums/af-zinas/atvert/cesis-skatama-rtuarhitekturas-fakultates-veidota-izstade-jaunie-arhitekti-latvijai-1

\section{July 17}

The fifth RTU Grand Graduation takes place at Spilve Airport, where approximately 1000 graduates of all faculties and study levels receive diplomas. Considering the situation of epidemiological safety and the 
restrictions on gatherings set in the country, the release takes place in the auto or drive-in format for the second year in a row.

https://www.rtu.lv/lv/universitate/masu-medijiem/zinas/atvert/

verienigi-nosvinets-rtu-lielais-auto-izlaidums-2021

\section{July 27}

Latvian swimmer, FMETA 2nd year master student Daniils Bobrovs makes his debut in the Summer Olympic Games (Tokyo), winning the 31st place in the $200 \mathrm{~m}$ long breaststroke distance, showing the time 2:14.25.

https://www.delfi.lv/sports/news/vasaras-olimpiskas-speles/zinas/ peldetajs-bobrovs-olimpiskajas-speles-debite-31-pozicija.d?id=53428339

\section{In July}

The Bachelor's and Master's study program «Administration of Customs and Taxes» of the International Business and Customs Institute of FEEM receives a certificate of recognition from the European Commission.

https://www.rtu.lv/lv/universitate/masu-medijiem/zinas/atvert/eiropas-komisijaatzist-rtu-muitas-izglitibu-novertejot-to-ka-vienu-no-labakajam-eiropas-savieniba

RTU is the only Baltic higher education institution to be among the 40 best higher education institutions in the section of the international rating «World's Universities with Real Impact» (WURI), which evaluates the capacity of higher education institutions in promoting entrepreneurship and developing the business environment. RTU ranks 31st, showing the best result not only in Latvia, but also in the Baltics. https://www.rtu.lv/lv/universitate/masu-medijiem/zinas/atvert/rtu-vieniga-nobaltijas-ieklust-reitinga-kura-novertets-universitates-ieguldijums-uznemejspejuveicinasana

\section{August 2}

Latvia becomes a full associate member of the European Organization for Nuclear Research, (CERN). Anita Muižniece, Minister of Education and Science; Toms Torims, RTU Professor and Latvian representative in CERN and Ilze Rūse, Director of the International Organizations and Human Rights Department of the Ministry of Foreign Affairs is taking part in the online solemn reception, which is taking place at both CERN's headquarters in Geneva and Riga; in the Ministry of Education and Science of Latvia, CERN Latvia will be represented by the Latvian Ambassador to the ANO in Geneva, Bakhtijors Hasans, and the ceremony will be attended by CERN Director General Fabiola Gianotti and other CERN management representatives.

https://www.rtu.lv/lv/universitate/masu-medijiem/zinas/atvert/ latvija-klust-par-pilntiesigu-cern-asocieto-dalibvalsti 


\section{August 7-8}

The RTU team (FEEM 1st year master student Viktorija Majorova, FCSIT 4th year student Diāna Zeltina, RTU Sports Centre Deputy Director Sanita Sveile and future RSU student Diāna Afanasjeva) wins a silver medal in the Latvian team championship table tennis in the highest league.

https://www.rtu.lv/lv/sports/sporta-centra-jaunumi/atvert/ rtu-galda-tenisistem-sudrabs-latvijas-cempionata-augstakaja-liga

\section{August 7-15}

For the tenth time, the largest chess festival «RTU Open 2021» in Northern Europe is taking place at the Kippsala International Exhibition Center, where German Grandmaster Aleksandrs Dončenko had won. https://www.rtu.lv/lv/universitate/masu-medijiem/zinas/atvert/starptautiskajasaha-festivala-rtu-open-2021-uzvar-vacijas-lielmeistars-aleksandrs-doncenko

\section{August 10-16}

In the competition of 46 member states and 180 participants, Džonatans Miks Melgalvis, a pupil of RTU EHS, wins a gold medal at the 17th International Geography Olympiad, which took place online this year and was organized by Turkey.

https://www.visc.gov.lv/lv/jaunums/skolnieks-no-latvijas-izcina-sajastarptautisko-olimpiazu-sezona-pirmo-zelta-medalu?fbclid=IwAR1LcAYR_ZCeHKU hT53Lie00RjRrXWcYTG4QJRHftNjKaw-Mp25kT9L6KXQ

\section{August 16}

Amendments to the Law on Higher Education Institutions enter into force, which envisages a reform of the management of higher education institutions, changing the management of the higher education system in Latvia and dividing higher education institutions into a new typology. https://www.delfi.lv/news/national/politics/ stajas-speka-grozijumi-augstskolu-likuma.d?id=53490277

\section{August 25}

For the sixth year in a row, RTU EHS wins the first place in the ranking of small schools of the Atis Kronvalds Foundation and the traveling award «Lielā pūce» (Big Owl).

https://www.rtu.lv/lv/universitate/masu-medijiem/zinas/atvert/rtuinzenierzinatnu-vidusskola-apliecina-savu-izcilibu-tradicionali-klustot-par-labakomazo-skolu-latvija 
The President of Latvia Egils Levits presents the Atis Kronvalds Award to Laura Fjodorova, a chemistry teacher at RTU EHS, for her contribution to the education of talented pupils and the management of pupils' scientific activities.

https://www.rtu.lv/lv/universitate/masu-medijiem/zinas/atvert/valsts-prezidentssveic-izv-skolotaju-lauru-fjodorovu-novertejot-ieguldijumu-talantigu-skolenuizglitosana

\section{August 28}

RTU women's team - Viktorija Majorova (FEEM), Liāna Zeltina (FCSIT), Kristīne Berežkova (FCE) - wins the 1st place in the Latvian XXXI Universiade competition in table tennis. V. Majorova and L. Zeltina also win in women's doubles. Eduards Spāgis (FCSIT) becomes the champion in the individual evaluation for men.

https://www.rtu.lv/lv/sports/sporta-centra-jaunumi/atvert/rtu-sportisti-izcinauzvaras-latvijas-xxxi-universiades-sacensibas-galda-tenisa?fbclid=IwAR3UGANCKA kZbFKhz2AoUKx9V9PRSEZ2mBbldFej7RiGcGcT6iDJpGNOIpM

\section{August 30}

With the decision of the Senate of RTU (Minutes No. 652):

- based on the decision of the FCE Council of 29 June 2021 (Minutes No. 011/2021), Mārtinšs Vilnitis was approved as the Dean of the FCE;

- a new version of the RTU Senate regulations have been approved, the procedure for its entry into force has been determined and it has been decided to forward it for approval at the RTU Constitutional Assembly.

The opening ceremony of the second «call» of the RTU Talent Program is taking place, in which the patron of the RTU Talent Program, Executive Vice President of the European Commission for An Economy that Works for People Valdis Dombrovskis, is also participating. https://www.rtu.lv/lv/universitate/masu-medijiem/zinas/atvert/rtu-talantuprogramma-studijas-uzsak-izcilakie-latvijas-jauniesi?fbclid=IwAR2_FPIbPIj9Bn4DCPSEhRz7-cbT2zgHHtl3XNG218UZ-HyE7cNhABBk4Y

\section{August 31}

The traditional meeting of the Rector Academician Leonìds Ribickis with RTU teaching staff and employees, starting the new study year, is taking place.

https://www.rtu.lv/lv/universitate/masu-medijiem/zinas/

atvert/31-augusta-tiessaistes-pasakuma-pirmkursniekus-iepazistinas-ar-rtu 
Online event «Startēšu RTU» is taking place, where 1st year students are introduced to the RTU study process, scientific, practical and extracurricular activities.

https://www.rtu.lv/lv/universitate/masu-medijiem/zinas/ atvert/31-augusta-tiessaistes-pasakuma-pirmkursniekus-iepazistinas-ar-rtu

A sitting of the RTU Constitutional Assembly is taking place, in which the regulations of the RTU Senate in a new version is approved.

Marking the 55th anniversary of the Faculty of Engineering Economics and Management, Dean Professor Elinna Gaile-Sarkane meets with the faculty teaching staff and employees, and the annual student selfgovernment event «IEVF lepnums» (Pride of the FEEM) takes place. https://www.rtu.lv/lv/universitate/masu-medijiem/zinas/atvert/ rtu-inzenierekonomikas-un-vadibas-fakultatei-55 